\title{
A Prediction Formula for The Estimation of Sediment Load in The Upper Reach of Al-Gharraf River
}

\author{
Mariam H. Daham \\ M.Sc. in Water Resources/Hydraulic \\ Engineering \\ College of Engineering-University of Baghdad \\ Baghdad, Iraq \\ E-mail: maryam.hadi95@gmail.com
}

\begin{abstract}
The presence of deposition in the river decreases the river flow capability's efficiency due to the absence of maintenance along the river. In This research, a new formula to evaluate the sediment capacity in the upstream part of Al-Gharraf River will be developed. The current study reach lies in Wasit province with a distance equal to $58 \mathrm{~km}$. The selected reach of the river was divided into thirteen stations. At each station, the suspended load and the bedload were collected from the river during a sampling period extended from February 2019 till July 2019. The samples were examined in the laboratory with a different set of sample tests. The formula was developed using data of ten stations, and the other three stations were used for validation. The determination coefficient, root mean square error and average relative error values were equal to $0.987,0.97 \mathrm{~kg} / \mathrm{s}$ and $7 \%$, respectively. Also, the values of the sediment load that resulted from the formula close to the results of the HEC-RAS model from a previous study, and the determination coefficient, root mean square error, and average relative error values were equal to $0.988,0.88 \mathrm{~kg} / \mathrm{s}$, and $7 \%$ respectively for the simulated model.
\end{abstract}

Keywords: Al-Gharraf River, empirical formula, sediment load.

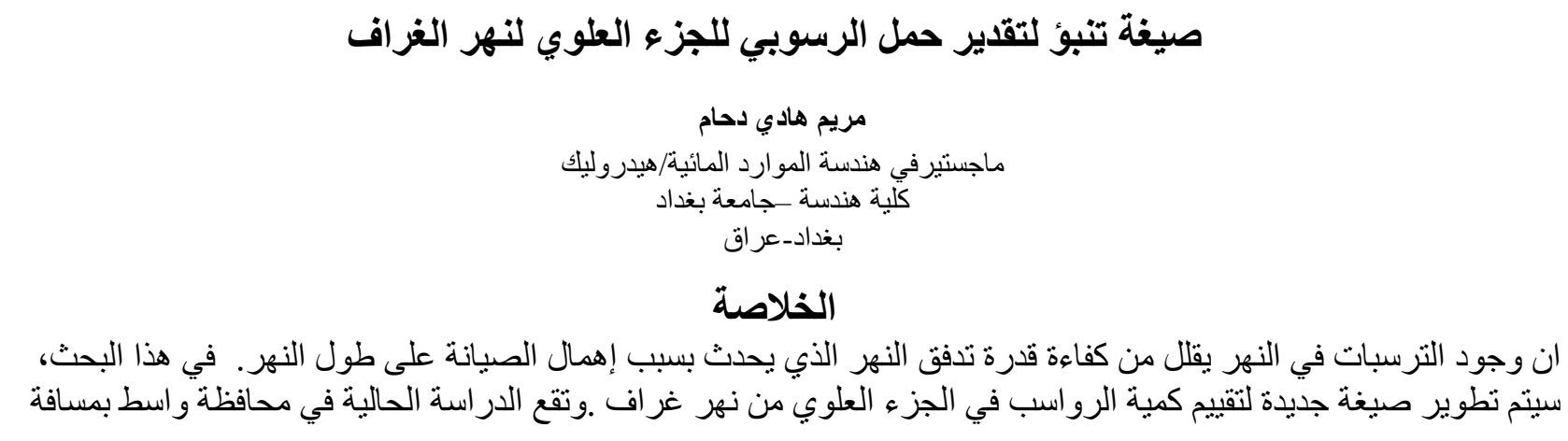

*Corresponding author

Peer review under the responsibility of University of Baghdad.

https://doi.org/10.31026/j.eng.2021.05.05

2520-3339 @ 2019 University of Baghdad. Production and hosting by Journal of Engineering.

This is an open access article under the CC BY4 license http://creativecommons.org/licenses/by /4.0/).

Article received: 5/2/2021

Article accepted: 16/3/2021

Article published:1/5/2021 
تساوي 58 كم، وتم تقسيم الامتداد المختار للنهر إلى ثلاث عشرة محطة، في كل محطة، تم جمع الحمل العالق وحمل القاع من النهر التهر

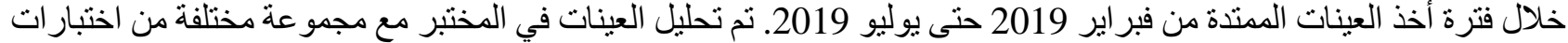
العينات .وقد وضعت الصيغة باستخدام بيانات عشرة محطات و استخدمت المحطات الثنلاث الأخرى للتحقق من صحتها ـوكان معامل فئل

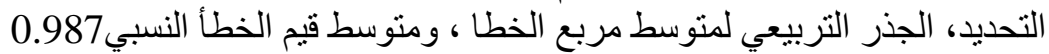

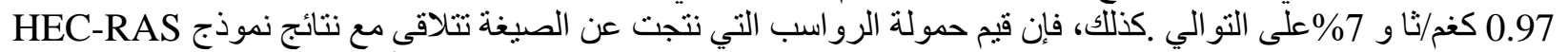

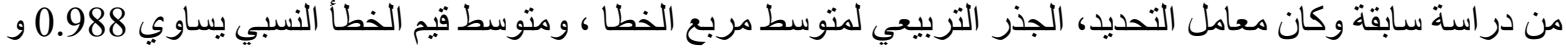

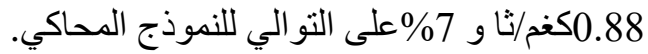

الكلمات الرئيسية :نهر الغراف ، صيغة تجريبية، الحمل الرسوبي،.

\section{INTRODUCTION}

Al-Gharraf River branches from the Tigris River, the main function Al-Gharraf River is delivering water to the cities situated in the center and south of Iraq. The total length of the Al-Gharraf River is $230 \mathrm{~km}$, and the selected length of this study reach is $58 \mathrm{~km}$ that lies in Wasit province. The design discharge of the river is $500 \mathrm{~m}^{3} / \mathrm{s}$ while the operation discharge is $350 \mathrm{~m}^{3} / \mathrm{s}$. The river's width is ranged between 150 to $80 \mathrm{~m}$, and the bed depth of the river is ranged between 3-8 $\mathrm{m}$. Numerous researchers predicted many formulas and empirical equation to estimate the amount of sediment transported by various flow conditions in different rivers and channels all over the world, these formulas and equations specified the transportations of sediments according to different limitation, but there was no formula or equation have a general form to be applied or used with the variable flow or sediments conditions or for different locations. (Van Rijn, 1984) proposed his bedload and suspended load equations from the average flow depth, the average velocity of sediment particles, and the concentration of sediment material in the bed layer. This equation is for the sand bed with soil diameter ranged between $0.1 \leq \mathrm{d} \leq 2.0 \mathrm{~mm}$ :

$\frac{q_{b}}{\mathrm{VH}}=0.005\left(\frac{v-v_{c r}}{\sqrt{\left(G_{\left.S^{-1}\right) \mathrm{g} D_{50}}\right.}}\right)^{2.4}\left(\frac{D_{50}}{H}\right)^{1.2}$

$\frac{q_{S}}{\mathrm{VH}}=0.012\left(\frac{v-v_{c r}}{\sqrt{\left(G_{s^{-1}} \mathrm{~g} D_{50}\right.}}\right)^{2.4}\left(\frac{D_{50}}{H}\right)\left(D_{*}\right)^{-0.6}$

$D_{*}=D_{50}\left(\frac{\left(G_{s}-1\right) \mathrm{g}}{v^{2}}\right)^{1 / 3}$

Where $q_{b}=$ bed load discharge ,tones/day. $q_{S}=$ suspended load discharge, tones/day. $v=$ average velocity, $m / s . v_{c r}=$ the critical velocity, $\mathrm{m} / \mathrm{s} . D_{50}=$ sediment diameter, $m m . D_{*}=$ particle parameter, dimensionless. $H=$ average flow depth, $m . v=$ kinematics viscosity, $m^{2} / s . G_{s}=$ specific gravity, dimensionless. $\mathrm{g}=$ gravity acceleration, $\mathrm{m} / \mathrm{s}^{2}$.(Hossain, 1992) derived a sediment concentration functional form by depending on dimensional analysis, this formula was conducted for flowrate, $\mathrm{Q}=5000 \mathrm{~m}^{3} / \mathrm{s}$, and it can be expressed as follows: 


$$
c_{t}=A\left(\mathrm{X}^{\mathrm{a}} \mathrm{Y}^{\mathrm{b}} \mathrm{Z}^{\mathrm{c}}\right)
$$

where, $A=6.496 \times 10^{5}$. X $=$ product of Froude number and energy gradient slope, dimensionless $(X=$ $\left.\frac{v S}{\sqrt{\mathrm{g} H}}\right) \cdot \mathrm{a}=0.745 . \mathrm{Y}=$ settling velocity ratio, dimensionless $. \mathrm{b}=0.633 . \mathrm{Z}=$ discharge ratio, dimensionless. $c=0.50 . c_{t}=$ rate of sediment concentration, $\mathrm{kg} / \mathrm{sec}$.

(Yang and Lim, 2003) derived an empirical equation for estimating sediment transport for river bed with particle size range between medium sand particles to very fine gravel $(0.833 \leq \mathrm{d} \leq 3.54 \mathrm{~mm})$, the following equation can be expressed as:

$G_{t}=k \frac{\gamma_{s}}{\gamma_{s}-\gamma} \tau_{0} \frac{u^{2}-u_{c}^{2}}{\omega_{s}}$

Where: $u=$ the grain shear velocity, $\mathrm{m} / \mathrm{s}$. and $\tau_{0}=$ the mean bed shear stress, $\mathrm{pa} . \quad k=12.5 . G_{t}=$ the sediment discharge per unit width $(\mathrm{kg} / \mathrm{m} / \mathrm{s})$ and $\gamma_{s}$, and $\gamma=$ the specific weight of soil and water respectively, $\mathrm{kg} / \mathrm{m}^{3} . u_{c}=$ critical shear velocity and $\omega_{s}=$ sediment fall velocity both in $\mathrm{m} / \mathrm{s}$.

(Imara and Jalil, 2009)Developed a semi-empirical equation to estimate the average sediment concentration. He used the decay function for the sediment concentration variation and velocity distribution. The following equation is used to estimate the average sediment concentration during the flood season in the tributaries of the Adhaim River:

$\frac{C_{a v}}{C_{b}}=\left(\frac{a(d-b) e^{b}}{d}\right)\left(1-e^{1 / b d}\right)$

$C_{b}=$ sediment concentration at depth $\mathrm{b}$ from the water surface, $\mathrm{kg} / \mathrm{sec}$. For convenience and easiness, the depth $\mathrm{b}=10 \mathrm{~cm}$ or $20 \mathrm{~cm} . C_{a v}=$ average sediment concentration, $\mathrm{kg} / \mathrm{sec} . \mathrm{d}=\mathrm{depth}$ of the water column, $m$.a $=$ the empirical constant that equals 10 based on Imara's field experience.

(Maatooq, et al.,2016) developed an empirical equation to predict the discharge of deposit in the lower part of the Al-Gharraf River located in the south of Iraq. The study's length was $14 \mathrm{~km}$ located between Al-Nasar City and Badaa regulator, divided into 13 stations along the river. He used the navigation device, Global positioning system (GPS), and ADCP device (Acoustic Doppler Current Profiler)to measure the hydraulic parameters. Depending on the obtained data of 13 stations on AlGharraf River, the new formula was estimated using the SPSS program (statistical package for social science).

$\emptyset_{s}=1316 \times\left(\frac{v}{\omega_{s}}\right)^{0.797} \times \frac{\left(\theta_{c r}\right)^{0.969}}{\left(D_{*}\right)^{1.822}} \times \frac{1}{(b / H)^{0.922}}$

Where: $\emptyset_{s}=$ rate of suspended sediment, dimensionless. $H=$ average depth, $m . b=$ channel depth, $m . v$ $=$ Average velocity, $\mathrm{m} / \mathrm{s} . \omega_{s}=$ sediment fall velocity, $\mathrm{m} / \mathrm{s} . D_{*}=$ particle parameter dimensionless term, $\theta_{c r}=$ Critical shield mobility parameter, dimensionless. The determination coefficient of the equation was equal to 0.94 . 
(Gunawan, et al.,2019) estimated the total sediment Load in the Cimanuk River and its branches, located in Indonesia, using rivers data and the analyzed samples during 2012 and 2014. Different formulas have been analyzed and compared, and the best formula that predicts accurate results for rivers was the Van Rijn method. (Daham and Abed, 2020) developed a one-dimensional deposit transportation model using HEC-RAS software for the upstream part of Al-Gharraf River to simulate the sediment amount in the river during different discharge values. The model predicted the hydraulic characteristics and evaluated the value of the manning coefficient in the steady-state in the river to be used to simulate the sediment model. The manning roughness value was equal to 0.026 . The sediment model was calibrated and validated during different periods in the river. The model simulation results show that the sediment and erosion issue was resolved by analyzing different manning roughness values, and the sedimentation accumulation was limited when lining selected parts of the river with concrete. While the erosion was limited when lining selected parts of the river with Grouted Riprap. (Daham and Abed, 2020) developed one and two-dimensional models by implementing HEC-RAS software to estimate unsteady flow characteristics for the upstream part of Al-Gharraf River. The model was calibrated and validated to evaluate the suitable value of Manning roughness for the river in an unsteady state, and the Manning value was 0.025 for the unsteady state. Several cases of flowrate were implemented in the models for comparing the one-dimensional model with the two-dimensional model. The results showed the two-dimensional model was more precise since it produced speed and water levels that converged with measured values. (Hatewar, et al.,2020) estimated sediment quantity in Jayakawadi Dam located in India by applying different empirical equations using sample data collected from 2011 to 2020 . The estimated values of sediment discharge were ranged between 0.68 to 4.8 ha.m/100 sq km/ year. (Thomas, et al., 2020) evaluated the sediment transport in Shihmen Reservoir located in Taiwan that applied the Recursive method to evaluate the sediment discharge in the reservoir using previous studies' data. (Zanke and Roland, 2020) developed a new bedload sediment transport formula from reforming thirteen sediment transport functions. Several elements have been taken into consideration like friction angle, shear stress, critical shear stress, and their effects on bedload transportation rates. The analysis results of empirical equations showed that friction angle has significantly affected the bedload discharge.

The present study's main objective is to conduct a new empirical formula to evaluate the deposit discharge in the upstream part of Al-Gharraf River since there are no previous studies that derive a formula for the current study reach.

\section{SEDIMENT SAMPLING}

The deposit samples were collected in the upstream part of Al-Gharraf River by distributing thirteen stations along the study reach, Fig.1. 


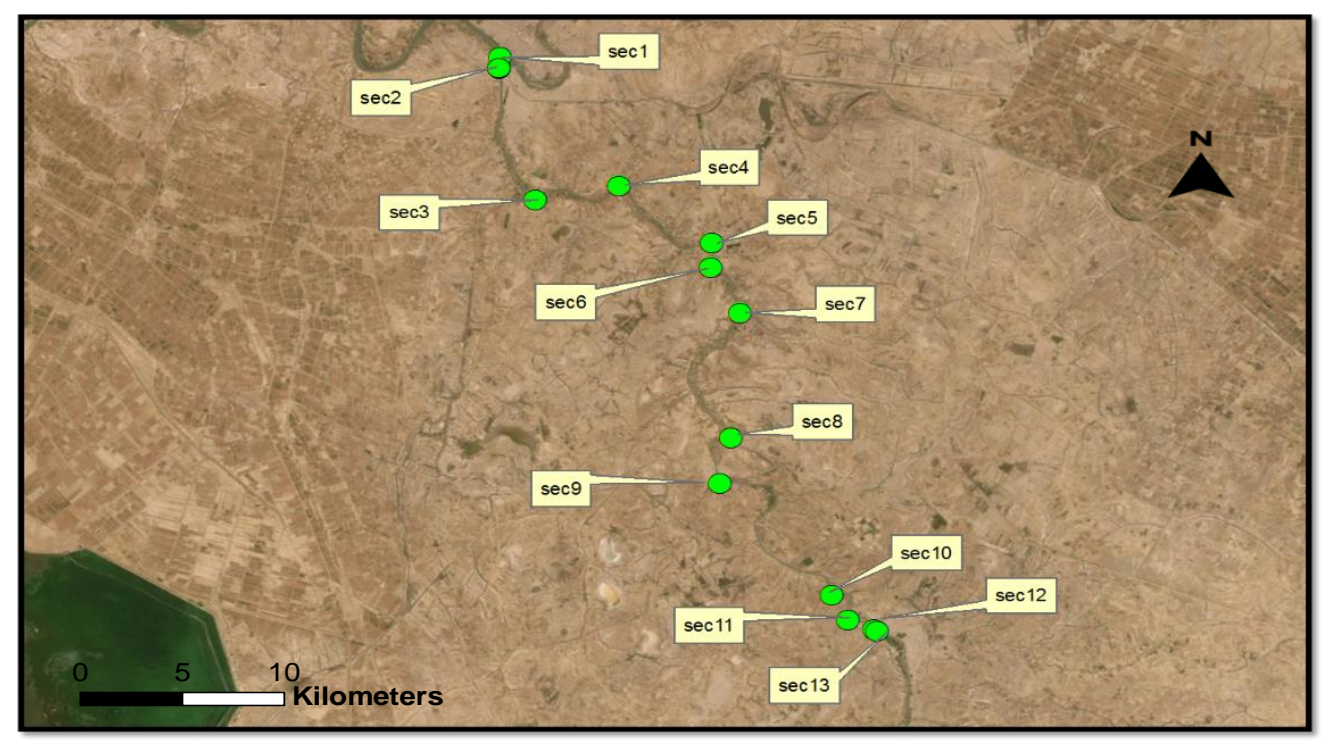

Figure1. The study reach and the distributed sediment stations, ARC-MAP(10.2).

The sampling period was extended from February till July 2019. For each cross-section, the suspended load sampler was gathered using the suspended sediment sampler Fig.2. The purpose of sampling the suspended sediment is to estimate the concentration of accumulated soil particles in the water column over the period. The concept of all suspended sediment samplers is similar. The design usually has two nozzles filled with tubes, one for entering the water inside the container and the tube's diameter equal to $8 \mathrm{~mm}$, while the other nozzle was for air exhaustion with a diameter equal to $6 \mathrm{~mm}$. Both tubes were installed at a depth equal to $3 \mathrm{~cm}$ from the sampler cap, and the volume of the sampler equal to one liter. According to the Interagency Committee on Water Resources (Shulites and Hill,1968), the locations of vertical samples were. In the present study, the suspended sediment sampler device was installed into a metal rod, and it lowered at each of the selected cross-sections at a single point midstream with depths equal to $0.2,0.6$, and 0.8 from the depth of the stream cross-sections. The outlet tube's purpose is for air exhaustion, which has a smaller diameter; once the air was expelled, the water entered from the inlet tube and is filled up with water, and the sample of sediment is gathered at each cross-section.Fig.3. will show the vertical locations of suspended samples. The samples of bedload were collected from the banks of the river and the bed of the stream at the selected sediment crosssections to specify the type and the grain size distribution curve of the river bed. The samples were collected using the Van Veen Grab device, which is two metal jaws connected to a cord, Fig.4 the bed material samples are collected by releasing Van Veen Grab device into the bed of the stream at the selected cross-section, and once the bed load is grabbed, the cord is pulled upward, and the two jaws are closed with bedload sample inside it. The bed load samples were gathered to obtain the particle distribution curve.

\section{LABORATORY TESTS}

To determine the sediment transport rate of Al-Gharraf River within the study reach, several laboratory tests must be conducted, such as analysis of suspended load samples and obtaining the sediment concentration value in $(\mathrm{mg} / \mathrm{l})$ each cross-section and that lead to conduct the amount of 
sediment discharge. Also, the analysis of bed material samples to obtain the grain size distribution curve at each selected cross-section resulted from the hydrometer test and sieve analysis test.

\subsection{Sieve Analysis}

Sieves are used to evaluate the particle-size distribution curve of material equals or greater than 2.0 $\mathrm{mm}$. Samples containing a percentage of clay and silt where it is a cohesive material can be extracted with washing and analyzed by a hydrometer. The particle size accumulated at pan through a sieve No.200 is further analyzed by a hydrometer, where this material is categorized as a cohesive particle (Guy,1969).

\subsection{Hydrometer Analysis}

The Hydrometer test was conducted to specify the grain size distribution curve for a fraction of soil smaller than sieve No. 200 (about $0.075 \mathrm{~mm}$ ) (Guy,1969). Finer particles of bed material samples are dispersed by soaking the soil sample into a dispersing agent and by rapid stirring to neutralize the charge between the soil sample particles. (The field sampling temperature was $20^{\circ} \mathrm{C}$ ). The laboratory results of the sieve analysis test and hydrometer test of bed material samples are presented as grain size distribution curves, as shown in fig.5. The laboratory analysis results for samples was described in Table1, and Fig.5.The soil type of bed of Al-Gharraf River was clayey silt.

\subsection{Concentration of Suspended Sediment}

The concentration of the gathered samples of suspended sediment of each cross-section was established using the filtration method. This laboratory analysis uses a filtration paper with a void diameter equal to $0.45 \mu \mathrm{m}$. The samples were filtered using a dry filtration paper (the filtration paper is weighed before), then the (filter paper and the sample) are placed in the oven for 15 minutes at a temperature of $105^{\circ} \mathrm{C}$ to remove the water from the sample. After that, the sample is placed out from the oven and weighed both the (sediment and filtration paper $=\mathrm{W}_{2}$ ) and finally, the concentration of suspended sediments at each cross-section is determined by using the following equation according to, (Mohammed, 2012):

$\mathrm{c}=\frac{W_{2}-W_{1}}{\overline{\mathrm{v}}}$

Where: $\mathrm{C}=$ suspended load concentration, $m g / l, W_{1}=$ the dry filter paperweight, $m g . W_{2}=$ the weightiness of filter paper and sediment after it dried, $m g . \bar{v}=$ the sample volume, $l$. The sediment discharge for each section was determined by multiplying the obtained sediment concentration by its water discharge. According to (Van Rijn, 1993), the equation can be written as follow $\mathrm{Q}$ Where : $\mathrm{Qs}=$ is the Total sediment transport rate, $\mathrm{kg} / \mathrm{sec} . \mathrm{Q}=$ water discharge, $\mathrm{m}^{3} / \mathrm{sec}$.

:Qs=CX 


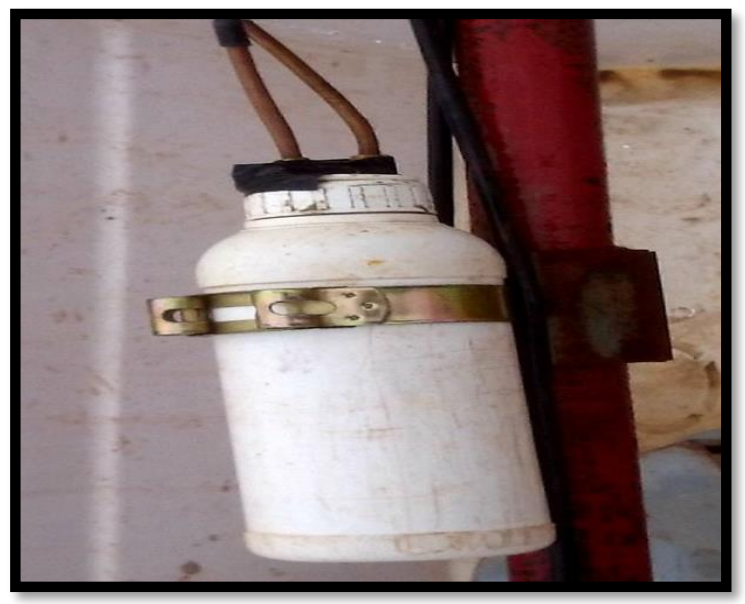

Figure 2.Suspended sediment sampler.

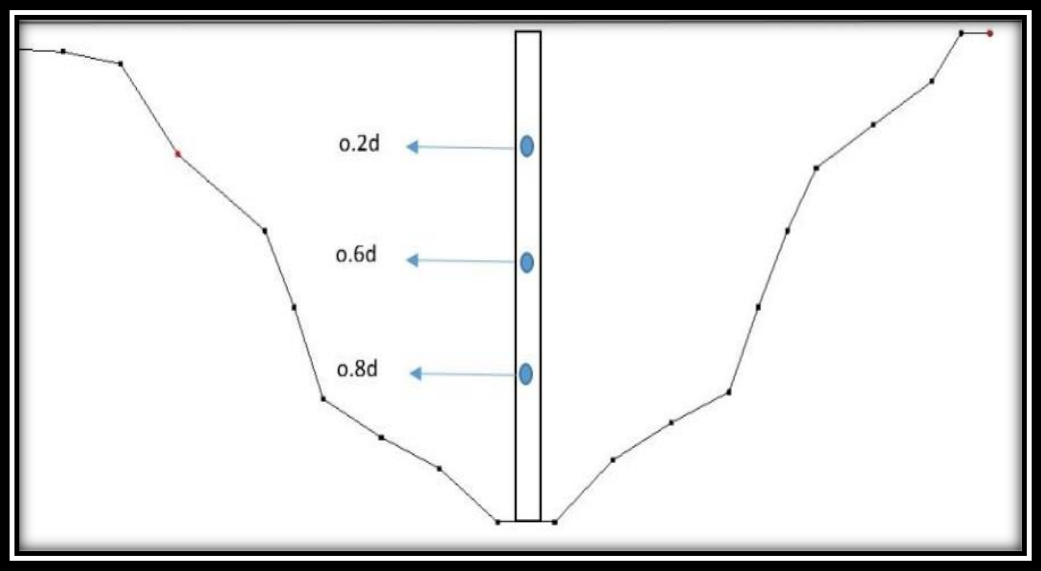

Figure 3. The location of suspended sediment samples.

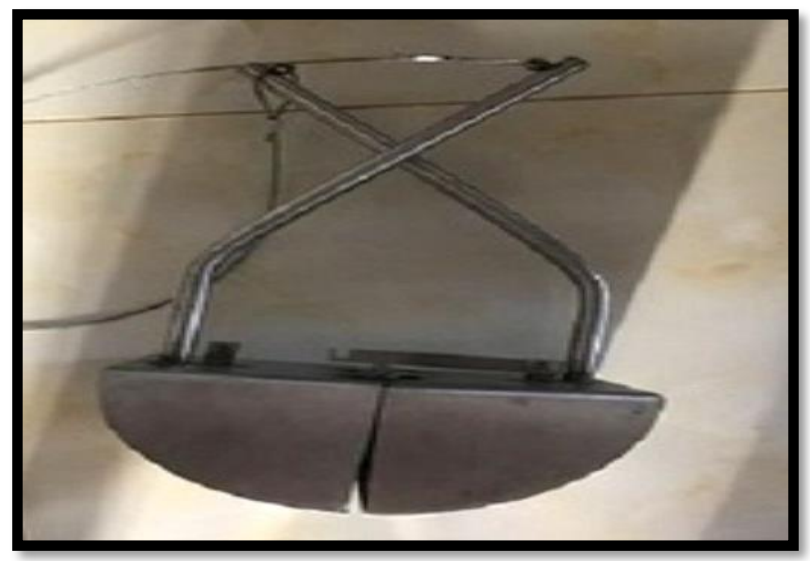

Figure 4. Van Veen Grab. 


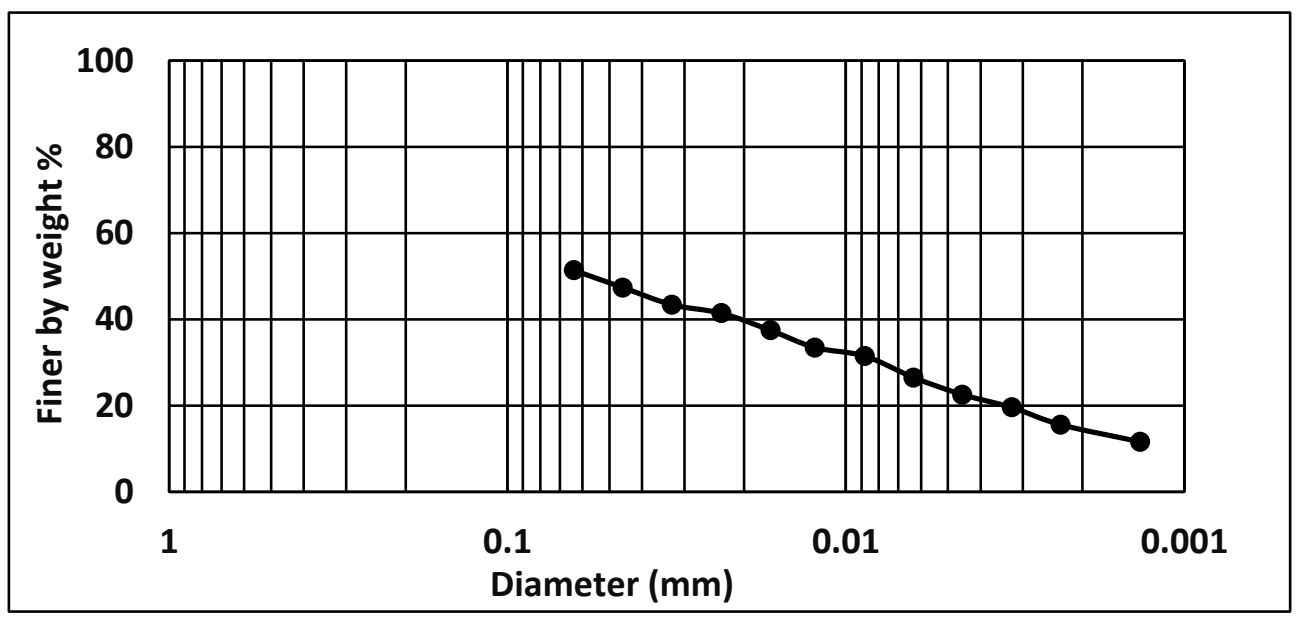

Figure 5. Grain size distribution curve for upstream of Al-Gharraf River.

Table 1. The measured field and laboratory measurements.

\begin{tabular}{|c|c|c|c|c|c|c|c|c|}
\hline $\begin{array}{c}\text { Sectio } \\
\text { n no }\end{array}$ & $\begin{array}{l}\mathbf{h} \\
\mathbf{m}\end{array}$ & $\begin{array}{c}\mathrm{V} \\
m / s\end{array}$ & $\begin{array}{l}\text { dso } \\
m m\end{array}$ & slope & $\begin{array}{c}\mathrm{v} \\
m^{2} / \mathrm{sec}\end{array}$ & $\begin{array}{c}\text { Flowrate } \\
m^{3} / s\end{array}$ & Gs & $\begin{array}{c}\text { Concentration } \\
\text { Of sediment } \\
m g / l \\
\end{array}$ \\
\hline 1 & 7.9 & 0.55 & 0.061 & 0.00008 & 0.000001 & 250 & 2.7 & 90 \\
\hline 2 & 8 & 0.45 & 0.056 & 0.00008 & 0.000001 & 240 & 2.71 & 85 \\
\hline 3 & 6 & 0.34 & 0.019 & 0.00008 & 0.000001 & 240 & 2.68 & 70 \\
\hline 4 & 5.9 & 0.32 & 0.019 & 0.00008 & 0.000001 & 237 & 2.65 & 80 \\
\hline 5 & 5 & 0.32 & 0.019 & 0.00008 & 0.000001 & 237 & 2.7 & 46 \\
\hline 6 & 4.9 & 0.3 & 0.02 & 0.00008 & 0.000001 & 210 & 2.65 & 40 \\
\hline 7 & 4.5 & 0.3 & 0.019 & 0.00008 & 0.000001 & 200 & 2.66 & 50 \\
\hline 8 & 4 & 0.25 & 0.019 & 0.00008 & 0.000001 & 180 & 2.65 & 50 \\
\hline 9 & 3.8 & 0.29 & 0.018 & 0.00008 & 0.000001 & 151 & 2.61 & 56 \\
\hline 10 & 4 & 0.27 & 0.018 & 0.00008 & 0.000001 & 140 & 2.65 & 60 \\
\hline 11 & 3.2 & 0.29 & 0.018 & 0.00008 & 0.000001 & 140 & 2.645 & 60 \\
\hline 12 & 3.01 & 0.4 & 0.018 & 0.00008 & 0.000001 & 140 & 2.645 & 60 \\
\hline 13 & 3 & 0.45 & 0.018 & 0.00008 & 0.000001 & 142 & 2.65 & 70 \\
\hline
\end{tabular}




\section{DEVELOPING A NEW EMPIRICAL FORMULA}

To develop a new formula for the upper reach of the Al-Gharraf River using dimensional analysis principles, several parameters must be taken into consideration, like the geometry of the river and hydraulic characteristics of the flow in the river. Moreover, the sediment characteristics and the soil type of the river bed involved with the field measurement. In this study, the influencing variables are:

$\mathrm{F}\left(h, q_{s}, V, d_{50}, s, w_{s}, \rho_{s}, \rho, v\right)=$ constant

Where:

$h=$ mean $\operatorname{depth}(m)$.

$q_{s}=$ sediment transportation rate $(\mathrm{kg} / \mathrm{s})$.

$V=$ mean velocity $(\mathrm{m} / \mathrm{sec})$.

$d_{50}=$ median diameter $(\mathrm{mm})$.

$s=$ The slope of the river, dimensionless.

$w_{s}=$ fall velocity of particles $(\mathrm{m} / \mathrm{s})$.

$\rho_{s}=$ density of sediment $\left(\mathrm{kg} / \mathrm{m}^{3}\right)$.

$\rho=$ density of water $\left(\mathrm{kg} / \mathrm{m}^{3}\right)$.

$v=$ kinematics viscosity of water $\left(\mathrm{m}^{2} / \mathrm{sec}\right)$.

The dimensional analysis is considered a useful tool to solve difficult problems by assuming and creating relationships between variables from the study's physical system. In this study, Buckingham's $\pi$-theorem was used, and by taking $\left(\rho, w_{S} H\right)$ as repeating variables were the first variable stand for the fluid characteristics, the second stand for the sediment property, and the last variable stand for the river's geometry property. Therefore, the total number of $\pi$-terms will be six, $F\{\pi 1, \pi 2, \pi 3, \pi 4, \pi 5$, $\pi 6,\}=$ constant and can be expressed as follow:

$\frac{q s}{\rho w_{s} h^{2}}=\pi 1$

$\frac{\rho s}{\rho}=\pi 2, \mathrm{~s}=\pi 3, \frac{V}{w_{s}}=\pi 4$

$\frac{v}{w_{s} h}=\pi 5$ and $\frac{d 50}{h}=\pi 6$

since $\frac{\rho s}{\rho}=G s$ and divided by $\pi 3$; thus a new term will be derived and, $\pi 7=\frac{G s}{s}$.

To decrease the number of $\pi$-terms, $\frac{\pi 5}{\pi 6}$, resulted in a new term $=\pi 8$, where

$\pi 8=\frac{v}{w_{s} d 50}$

Then the formula form will be $q s=\rho w_{s} h^{2} \times \frac{v}{w_{s} d 50} \times \frac{G s}{s} \times \frac{V}{w_{s}}$

The data of 10 cross-sections were used to develop the formula using the SPSS program. The formula can be written as follows:

$=1.7 \times 10^{-6}\left(w_{s} \rho h^{2} \times\left(\frac{v}{w_{s} d 50}\right)^{0.762} \times\left(\frac{G s}{s}\right)\left(\frac{V}{w_{s}}\right)^{0.85}\right) q_{s}$

$q_{s}=$ sediment transportation rate $(\mathrm{kg} / \mathrm{s})$.

$h=$ mean $\operatorname{depth}(m)$. 
$V=$ mean velocity $(\mathrm{m} / \mathrm{sec})$.

$d_{50}=$ median diameter $(\mathrm{mm})$.

$s=$ The slope of the river, dimensionless.

$w_{s}=$ fall velocity of particles $(\mathrm{m} / \mathrm{s})$.

$\nu=$ kinematics viscosity of water $\left(\mathrm{m}^{2} / \mathrm{sec}\right)$.

$\rho=$ density of water $\left(\mathrm{kg} / \mathrm{m}^{3}\right)$.

$G s=$ specific gravity, dimensionless.

The other three sections' data were used for validation of the formula, and the determination coefficient, $\mathrm{R}^{2}$ was equal to 0.987 . The RMSE root mean square error was equal to $0.97 \mathrm{~kg} / \mathrm{s}$ while the mean relative error was equal to 7\%. Table 2 will illustrate the results of the observed and computed sediment flowrate values. These results were compared to the results conducted by (Daham and Abed, 2020) that used HEC-RAS software for model simulation. The determination coefficient, RMSE, and mean RE were equal to $0.988,0.88 \mathrm{~kg} / \mathrm{s}$ and7\% respectively between measured field data and simulated data from simulating sediment transport model by using HEC-RAS software. The hydraulic data (including flowrate and water level values) in this study was measured by (MoWR, 2019).

Table 2.The comparison between the observed and the computed sediment loads.

\begin{tabular}{|c|c|c|c|c|c|}
\hline $\begin{array}{c}\text { Section } \\
\text { no }\end{array}$ & $\begin{array}{c}\text { qs } \\
\text { measured } \\
\mathbf{k g} / \mathbf{s}\end{array}$ & $\begin{array}{c}\text { qs computed } \\
\text { by formula } \\
\mathbf{k g} / \mathbf{s}\end{array}$ & $\begin{array}{c}\text { qs simulated } \\
\text { using HEC- } \\
\mathbf{R A S} \\
\mathbf{k g} / \mathbf{s}\end{array}$ & $\begin{array}{c}\text { the relative } \\
\text { error for } \\
\text { formula } \\
\mathbf{\%}\end{array}$ & $\begin{array}{c}\text { the relative error } \\
\text { for the HEC- } \\
\text { RAS model } \\
\mathbf{\%}\end{array}$ \\
\hline 1 & 22.5 & 23.0 & 22.5 & 2.0 & 2 \\
\hline 2 & 20.5 & 21.0 & 20.5 & 2.0 & 3 \\
\hline 3 & 17.0 & 17.7 & 17.5 & 4.0 & 3 \\
\hline 4 & 19.0 & 20.4 & 20.5 & 7.0 & 8 \\
\hline 5 & 11.6 & 12.0 & 11.9 & 3.0 & 2.6 \\
\hline 6 & 8.5 & 9.5 & 9.0 & 11.7 & 5.9 \\
\hline 7 & 10.0 & 12.0 & 11.9 & 20.0 & 19 \\
\hline 8 & 9.0 & 7.35 & 7.5 & 18.0 & 16 \\
\hline 9 & 8.5 & 8.43 & 8.0 & 0.8 & 5.8 \\
\hline 10 & 8.4 & 8.0 & 8.0 & 4.7 & 4.7 \\
\hline 11 & 8.4 & 8.0 & 8.0 & 4.7 & 4.7 \\
\hline 12 & 8.4 & 8.0 & 8.0 & 4.7 & 4.7 \\
\hline 13 & 10.0 & 9.0 & 9.1 & 10.0 & 9 \\
\hline
\end{tabular}

\section{LIMITATION OF THE PREDICTED FORMULA}

The developed transport formula was established using data that measured during the field period extended for five months. The formula was derived using the data of ten cross-sections, then it was validated using the data of the other three stations. The computed formula is applied on the rivers that having the following criteria: 
- The soil type of river bed was clayey silt with a composition of $90 \%$ silt and $10 \%$ clay.

- The flowrate values were ranged between (140 to 250$) \mathrm{m}^{3} / \mathrm{s}$.

- Both the depth and slope of the river were 3 to $8 \mathrm{~m}$ and $8 \mathrm{~cm} / \mathrm{km}$, respectively.

- The velocity values ranged from 0.25 to $0.55 \mathrm{~m} / \mathrm{s}$.

\section{CONCLUSIONS}

From the obtained results of the present study, the following conclusions can be extracted:

- The developed formula is valid for rivers with similar discharge conditions, bed configuration, and river geometry of the present study reach.

- Good agreement between the observed and evaluated sediment discharge with the value of determination coefficient equal to 0.987 , the RMSE, root mean square error was equal to 0.97 $\mathrm{kg} / \mathrm{s}$, and the mean relative error was equal to $7 \%$.

- The empirical formula results converged with the HEC-RAS model results for sediment transport simulation since the determination coefficient's value was 0.987 for the formula and 0.988 for the HEC-RAS model. Also, RMSE and mean RE values for the formula were 0.97 $\mathrm{kg} / \mathrm{s}$ and $7 \%$, respectively, while these values for the HEC-RAS model were $0.88 \mathrm{~kg} / \mathrm{s}$ and $7 \%$, respectively.

\section{REFERENCES}

- Daham, M., and Abed, B., 2020. Simulation of Sediment Transport in the Upper Reach of AlGharraf River. Materials Science and Engineering, 901(1),1-11. Available at: https://iopscience.iop.org/article/10.1088/1757-899X/901/1/012012.

- Daham, M., and Abed, B,2020. One and Two-Dimensional Hydraulic Simulation of a Reach in Al-Gharraf River. Journal of Engineering, 7(26), 28-44. Available at:http://joe.uobaghdad.edu.iq.

- Gunawan, T., Daud, A., Haki, H., and Sarino, 2019. The Estimation of Total Sediments Load in River Tributary for Sustainable Resources Management. IOP Conference Series: Earth and Environmental Science, 248,1-11. Available at: https://iopscience.iop.org/article/10.1088/1755-1315/248/1/012079/pdf.

- Guy, H.,1969. A laboratory Theory and methods for sediment analysis. United States Geological Survey.

- Hatewar, P., Birajdar, S., Howal, A, and Badhe, A., 2020. Sedimentation Analysis Using Empirical Formula. International Research Journal of Engineering and Technology (IRJET),7(7),88-875 .Available at: https://www.irjet.net/archives/V7/i7/IRJET-V7I7154.pdf.

- Hossain, M., 1992. Total sediment load in the lower Ganges Jamuna.J.Instn Engrs, Bangladesh, 20(3), 17-2. 
- Imara, N., and Jalil, H., 2009. Estimation Of Average Suspended Sediment Concentration In A Flow Depth By One Sample. Eng. \& Tech. Journal,27(1),1-9. Available at: https://www.uotechnology.edu.iq/tec_magaz/volume272009/No.1.2009/Abstract/Abstract_14 .pdf.

- Maatooq, J., Omran, H., and Aliwe, H., 2016. Empirical Formula for Estimation the Sediment Load in Shat AL-Gharaf River.Basrah Journal for Engineering Sciences,16(1),38-41. Available at: https://www.iasj.net/iasj/article/133214.

- Ministry of Water Resources MoWR, 2019. Data on the water levels and hydraulic information of Gharraf River.

- Mohammed, H., 2012. Estimation of Sediment Quantity upstream of Al-Abbasiya barrage in Euphrates River.Master Thesis, Department of Civil Engineering, University of Kufa.

- Shulites, S., and Hill, R. D.,1968. Formulas for bedload transport Hydraulic Laboratory. Interagency Committee on Water Resources, USA.

- Thomas, K., Chen, W., Lin, B., and Seeboonruang, U., 2020. Evaluation of the Sediment Delivery Distributed ( SEDD ) Model in the Shihmen Reservoir Watershed. Sustainability, 12(6221),1-21; doi:10.3390/su12156221.

- Van Rijin, 1984.Principle of Sediment transport in River Estuaries and Coastal Seas. Department of Physical Geography, University of Utrecht.

- Van Rijin, 1993. Principles of Sediment Transport in Rivers. Aqua Publications, Amsterdam, the Netherlands.

- Yang, Sh. and Lim, S., 2003. Total Load Transport Formula for Flow in Alluvial Channels.Journal of Hydraulic. ASCE, 129(1),1-8. Available at: https://www.researchgate.net/publication/245297137_Aspect_Ratio_to_Maximize_Sediment _Transport_in_Rigid_Bank_Channels.

- Zanke, U. and Roland, A., 2020. Sediment bed-load transport: A standardized notation. Geosciences (Switzerland),10(9),1-21. Available at: https://www.mdpi.com/2076$\underline{3263 / 10 / 9 / 368}$. 